\title{
A CASE FOR SOME NORMATIVE CONTENT IN SOUTH AFRICAN TRUST LAW
}

\author{
Eben $\mathrm{Nel}^{*}$ \\ BJuris LLB LLM LLD PGD(Financial Planning) \\ Advocate of the High Court of South Africa \\ Research Associate, Faculty of Law \\ Nelson Mandela Metropolitan University \\ Port Elizabeth
}

\section{SUMMARY}

The nature and content of the fiduciary duty in South African trust law is discussed and the principles and theory of fiduciary law are set against the value system underpinning such law. The aspect of trust and the role of power within the fiduciary relationship, with particular reference to the duty of care as inherent ingredient of the fiduciary function, are investigated. While the fiduciary duty cannot be separated from the duties of a trustee, it is submitted that it is made up of more than a duty of care, and also includes aspects such as impartiality, independence, accountability, loyalty and good faith. The legislated duties of the company director, namely care, diligence and skill, are compared with the contents of the fiduciary duties of trustees, with reference to traditional viewpoints in other jurisdictions, such as the profit and conflict rule, the duty of loyalty and the law of equity. Against this background the question is posed whether the fiduciary duty of the trustee in South Africa is an expression of positive law only, or whether some normative content has actually infiltrated the application thereof. It is submitted that, as matters of a fiduciary nature are closely interwoven with moral and social aspects, the application of positive law when dealing with the fiduciary duty of trustees has indeed been influenced by some normative thinking.

\section{$1 \quad$ INTRODUCTION}

In this article, the nature of the fiduciary duty in South African law, and particularly that of the trustee, is considered, and the question is asked whether it originates from positive or normative law. While positive legal theory seeks to explain the what, why and how of law, normative legal theories search for the value system underlying positive law. Positive law answers the doctrine (the principles and theory) behind the reasons for (causes of) and effects (consequences) of the particular aspect of law, without an explicit evaluation of the desirability thereof. Normative legal theory, on the other hand, is evaluative in nature - whether by searching for the most ideal rule, by critically investigating the justification for the rule, or by evaluating the 
moral or ethical nature of the particular rule. ${ }^{1}$ However, there is not necessarily a clear line between positive and normative legal theory, of which Ronald Dworkin's theory of "law as integrity" is an example, when it requires that a law should both fit and justify the existing legal landscape - thus attempting to combine positive doctrinal theory and justificatory normative theory.

\section{THE FIDUCIARY RELATIONSHIP}

The nature of a fiduciary relationship is one of trust and good faith and was once thought to be an improbability in commercial relationships. ${ }^{3}$ The term "fiduciary" means "trust-like" or "appertaining to trust" and has developed as an integral part of many common-law systems. ${ }^{4}$ "Our highest court has established that a fiduciary relationship exists "where one man stands to another in a position of confidence involving a duty to protect the interests of that other". ${ }^{5}$ The fiduciary duty has even been referred to as the "highest duty known to the law", 6 but such accolades still do not clarify the true theoretical base thereof.

A fiduciary relationship may develop in a variety of ways, and Idensohn, ${ }^{8}$ while advocating clearer fiduciary principles, distinguishes between four possible theories underlying the existence of a fiduciary relationship, namely:

* This article is based partly on research done towards an LLD thesis titled "The Business Trust and Its Role as an Entity in the Financial Environment" (Nelson Mandela Metropolitan University, Port Elizabeth, 2012) with Professor Vivienne Lawack as promoter and Professor Adriaan Van der Walt as co-promoter.

1 See Savaneli "The Co-existence of Public Positive Law and the Private Normative Order: The Constant Spiral of the Developing Interaction and Mutual Transition Between Positive Law and Normative Order" 2010 The Journal Jurisprudence www.jurisprudence.com.au/juris6/ savaneli.pdf (accessed 2015-03-09) 247. For definitions of concepts see http://lsolum. typepad.com/legal_theory_lexicon/2003/12/legaltheoryle.html (accessed 2015-02-25).

2 See Madry "Global Concepts, Local Rules, Practices of Adjudication and Ronald Dworkin's Law as Integrity" 200524 Law and Philosophy 211, for critical analysis of the law as integrity theory.

3 Glover submitted in Commercial Equity: Fiduciary Relationships (1995) 395, that "(t)he heart of commerce was conceived as certainty and despatch - which left little room for conscientious obligations and the balancing of rival equities". See also Rotman "Fiduciary Law's 'Holy Grail': Reconciling Theory and Practice in Fiduciary Jurisprudence" 201191 Boston University LR 921, for a discussion on fiduciary law.

4 See Watt Trusts and Equity (2006) 337.

5 Robinson v Randfontein Estates Gold Mining Co Ltd 1921 AD 168 177. See Valsan Understanding Fiduciary Duties: Conflict of Interest and Proper Exercise of Judgment in Private Law (Doctor of Civil Law thesis McGill University, Montreal, 2012) in general www.collectionscanada.gc.ca/obj/thesescanada/vol2/.../TC-QMM-110522 (accessed 201502-24).

6 See Bogle "The Fiduciary Principle: No Man Can Serve Two Masters" 20091 The Journal of Portfolio Management http://johncboglr.com/worldpress (accessed 2014-12-28) 12.

7 Idensohn "Towards a Theoretical Framework of Fiduciary Principles: Volvo (SA) (Pty) Ltd v Yssel 2009 (4) All SA 497 (SCA)" 20102 Speculum Juris 124 142, submits that the term "fiduciary" "remains an ill-defined and misleading term; a vague elusive "concept in search of principle"'. In Hofer v Kevitt 1996 (2) SA 402 (C) 407B the concept of a fiduciary duty has been described as being with "no clearly defined meaning". See Miller "A Theory of Fiduciary Liability" 2011 56(2) McGill LJ 235, who also submits that the fiduciary concept has been developed in "an unprincipled manner". In Phillips v Fieldstone Africa (Pty) Ltd 2004 (1) All SA 150 (SCA) 159, the court did state that "( $\mathrm{t}$ )here is no magic in the term 'fiduciary duty'".

820102 Speculum Juris 143. 
the reliance theory, when one person places trust in another; the contractual or voluntary assumption theory, when the trusted person agrees to act in the interests of the trusting person; the vulnerability or unequal relationship theory, where one person has some power over the other; and, the property theory, where one person has control over property that is beneficially owned by another. ${ }^{9}$

The aspect of trust can most probably be regarded as the common denominator present in all fiduciary relationships. ${ }^{10}$ The trust concept in this context, however, includes both the situation where someone places trust in another and the situation where the responsible person's position of trust is a result of an agreement, or is born out of a position of power or responsibility whether it includes control over property or not.

In reference to Volvo (SA) (Pty) Ltd $v$ Yssel, Idensohn ${ }^{11}$ states that in applying the reliance theory, ${ }^{12}$ although it is not a prerequisite for a mutual understanding between the parties that the one should relinquish his or her own interests and act on behalf of the other, the beneficiary must have "relax(ed) the care and vigilance it would and should ordinarily have exercised in dealing with a stranger". Such relaxation or reliance by the beneficiary must have been justified in the particular circumstances. ${ }^{13}$

In the Canadian case of Galambas $v$ Perez ${ }^{14}$ the Supreme Court held that not all power-dependency relationships are necessarily fiduciary in nature. The Court further determined that an ad hoc fiduciary relationship can only exist if there was some form of undertaking by the fiduciary - either expressed or implied - to act in the best interest of the other party. In the case of per se fiduciary relationships, this undertaking will be found in the nature of the relationship itself. The court also held that for a fiduciary relationship to exist the fiduciary must have some form of discretionary power to affect the other party's interests. ${ }^{15}$ This principle was confirmed in Volvo (SA) (Pty) Ltd v $Y s s e l,{ }^{16}$ where the court stated that "evidence of a mutual understanding that one party has relinquished its own self-interest and agreed to act solely on

9 Ibid. Last-mentioned will include the trust position where the beneficiary has only a contingent right (spes).

10 See Dharmaratne "A Consideration of Whether Directors Should Stand in a Fiduciary Relationship with the Company's Related and Inter-related Companies" www.cgblaw. co.za/fiduciary-relationship.pdf (accessed 2014-12-28) 12.

1120102 Speculum Juris 148.

12 See Alces "Debunking the Corporate Fiduciary Myth" 2009 35(2) Journal of Corporation Law 20 , for a discussion on the morally based "reliance theory", which requires that a fiduciary duty exists where one person "reposes trust, confidence or reliance" on another, with the expectation that the fiduciary will not abuse such trust https://www.law.illinois.edu/_ shared/pdfs/Debunking\%20the\%20Corporate\%20Fiduciary\%20Myth.pdf (accessed 2015-0312).

13 Idensohn 20102 Speculum Juris 148, where he refers to the characteristics of fiduciary relationships identified in Phillips v Fieldstone Africa (Pty) Ltd 2004 (3) SA 465 (SCA), namely: scope for the exercise of some discretion or power; that power or discretion can be used unilaterally so as to affect the beneficiary's legal or practical interests; and, a peculiar vulnerability to the exercise of that discretion or power.

14 [2009] 3 SCR 247.

15 See Galambas v Perez supra par 50, 63-64, 66, 74-75, 77, 80 and 84-86.

16 Supra par 16, with reference to Dolton v Capitol Federal Savings and Loan Association, 642 p 2d 21 (Colo. App. 1982) 23-24. 
behalf of the other party", is necessary to indicate a fiduciary relationship outside of the established categories. The liability theory supported by the courts in both the Galambas and Volvo cases rests upon the existence of a fiduciary relationship, but does not reveal the true nature and the full extent of fiduciary duties. ${ }^{17}$

Leslie, ${ }^{18}$ however, submits that the fiduciary relationship is a particular type of legal relationship, distinct from other relationships which may result from a contract, where the fiduciary is endowed with discretionary power over the interests of one or more third parties, flowing from the nature and contents of the fiduciary relationship. In an attempt to determine the crystallised content of such rules and norms, some have tried to reformulate the content of the duty of care inherent to the fiduciary function. ${ }^{19}$

\section{THE FIDUCIARY DUTY}

Watt ${ }^{20}$ submits that the fiduciary duty is "the defining duty of trusteeship", with the two principle obligations being the trustee's duty not to allow his interests to conflict with that of the trust, and not to make an unauthorised profit from this position of trust or from the trust property. In the recent Kidbrooke case ${ }^{21}$ the court confirms that the conflict of interest the trustees experienced "was in manifest breach of their duties to the Trust and the rights holders as beneficiaries" and that, in reference to the removal of trustees, "dishonesty, gross inefficiency or untrustworthiness" need not necessarily be present. ${ }^{22}$ The court further finds that the said trustee was personally so involved in the affairs of the trust that it "(had) caused him to misconstrue in material respects the nature of his role, duties and responsibilities as trustee.,"23

As far as the fiduciary duty is concerned, Du Toit ${ }^{24}$ identified four essential duties, which he refers to as "the principal component parts of a trustee's general fiduciary duty", namely the duty of care (including the administrative role of trusteeship), the duty of impartiality (acting in utmost good faith and in the best interest of the beneficiaries, without the trustee making any undue

17 See Miller 2011 56(2) McGill LJ 235, and his quest for a clear account of "the nature and normative significance of the fiduciary relationship".

18 "Trusting Trustees: Fiduciary Duties and the Limits of Default Rules" 200594 Georgetown LJ 11 and 2. Miller 2011 56(2) McGill LJ 235, states that "fiduciary duties are explicable solely in terms of normatively salient qualities of the fiduciary relationship".

19 Leslie 200594 Georgetown LJ 2, interprets these attempts, including new provisions of the Uniform Trust Code, as an interference with the basic principles of the duty of loyalty and care, replacing it with general principles of contract.

20 Trusts and Equity 337 and 343-364.

21 Kidbrooke Place Management Association v Walton WCD 25-03-2015 case no 18932/2012 par 47 and 53.

22 Kidbrooke Place Management Association v Walton supra par 53, and compare Volkwyn NO $\checkmark$ Clarke and Damant 1946 WLD 456 464, for a different approach.

23 Kidbrooke Place Management Association v Walton supra par 54.

24 "The Fiduciary Office of Trustee and the Protection of Contingent Trust Beneficiaries" 20073 Stellenbosch LR 469476 . Compare the list of fiduciary duties of directors of companies prescribed by Companies Act 71 of 2008 , as summarised and discussed in Blackman, Jooste et al Commentary on the Companies Act Vol 2 (2008) 208, including the manner in which their powers are exercised, the application of their discretion, the prevention of conflict of their personal interest, the application of good faith, the prohibition against secret profits, the care regarding certain economic opportunities, competing with the company and the misuse of confidential information. 
profit), the duty of independence (especially independence of judgment) and the duty of accountability (by keeping proper accounts). He confirms the fluidity of the fiduciary obligation and adds that the ambit of the fiduciary duty is subject to change in future. He submits that the above four elements have materialised in South African law so far. Particular factual circumstances may cause further components to come to the fore. ${ }^{25}$

In both the Canadian and the South African cases the existence of the fiduciary duty was based on some form of undertaking by the fiduciary, which may indicate a duty solely based on a contractual relationship. ${ }^{26}$ Leslie $^{27}$ is supported in her statement that "fiduciary duties are most effective when they function both as legal rules and moral norms", adding that equating fiduciary duties as mere terms of a contract "strips them of their normative content, which ultimately undermines fiduciary law's ability to support and reinforce efficient social norms". ${ }^{28}$ It is submitted that the fiduciary duty cannot be demystified by an over-simplification of its source and nature. Although a socalled triad of fiduciary duties for directors, namely loyalty, due care and good faith, has apparently developed in Delaware's corporate-law environment, it was decided that the requirement of good faith was at the core of the duty of loyalty, and does not constitute a separate fiduciary duty. ${ }^{29}$ The concept of good faith is thus an indicator of the state of mind of the fiduciary and not a separate requirement. ${ }^{30}$

Laby ${ }^{31}$ describes the duty of loyalty in general as a negative duty not to harm the beneficiary, while the duty of care is a positive duty based on the control and discretion vesting in the trustee. Included in the duty of loyalty, however, is the positive duty of the trustee to segregate trust property from his own assets. The duty of care will include the responsibility of the trustee to protect the trust property and to inform himself of all material information relating to the trust and its affairs. ${ }^{32}$

The duty-of-loyalty rule requires a trustee "to administer the trust solely in the interest of the beneficiary", which has become known as the "sole-interest" rule. ${ }^{33}$ Langbein criticises this rule and indicates that it is unsound in various

25 Du Toit 20073 Stellenbosch LR 476. See his detailed discussion on the development of these components through case law.

26 See Alces 2009 35(2) Journal of Corporation Law 30, stating that courts often insist that creditors of companies are not owed fiduciary duties because their relationships with the corporation are governed by contract, and further that "all fiduciary relationships are contractual, (but that) not all contractual relationships are fiduciary".

27200594 Georgetown LJ 1 and 2.

28 Ibid.

29 See Strine, Hammermesh, Balotti and Gorris Loyalty's Core Demand: The Disciplinary Role of Good Faith in Corporation Law Discussion Paper No 630 3/2009, Harvard Law School http://www.law.harvard.edu/ programs/olincenter/papers/pdf/Strine630.pdf (accessed 201502-18) 1, and their reference to the decision in Stone $v$ Ritter 911 A.2d 362 (Del.2006). Compare also Cede \& Co v Technicolor Inc. 634 A.2d 345 (Del.1993).

30 Strine et al Discussion Paper No 630 3/2009, Harvard Law School http://www.law. harvard.edu/programs/olincenter/papers/pdf/Strine630.pdf (accessed 2015-02-18) 4.

31 "Resolving Conflicts of Duty in Fiduciary Relationships" 2005 54(75) American University LR 75106.

32 Laby 2005 54(75) American University LR 110 and 112.

33 Langbein "Questioning the Trust Law Duty of Loyalty: Sole Interest or Best Interest? 2005 114 Yale LJ 931. 
aspects as its "uncompromising rigidity" does not allow any further enquiry into the decision taken by the trustee. ${ }^{34} \mathrm{He}$ argues in favour of a "bestinterest" test, which will be an actualisation of the underlying purpose of the duty of loyalty that the sole-interest rule is supposed to serve, namely the best interest of the beneficiary. He submits that if a transaction is in the best interest of the beneficiary it also serves the duty of loyalty best, even if at the same time the trustee also derives a benefit therefrom. ${ }^{35}$

\section{THE FIDUCIARY DUTY OF DIRECTORS}

The Companies Act 71 of 2008 contains a partial codification of the fiduciary duty of directors and incorporates principles consonant with the common law requirements of a duty of trust, namely care, diligence, skill, good faith, proper purpose and best interest. ${ }^{36}$ The requirements of "care, diligence and skill" are used in the Companies Act to describe the duty of directors when exercising the powers and performing the functions of a director. It further states that directors will be "held liable in accordance with the principles of the common law relating to breach of a fiduciary duty, for any loss, damages or costs sustained by the company as a consequence of any breach by the director of [such requirements]". ${ }^{37}$ "Care" means concern, serious attention, consideration and protection; "diligence" speaks of proper care and effort, while the term "skill" refers to proficiency, expertness, and ability. ${ }^{38}$ Performing with care, diligence and skill in company law means that all actions must be taken in good faith, with a proper purpose and in the best interest of the company. Some argue that a requirement of care (and for that matter diligence and skill) is not fiduciary in nature, because fiduciary relationships have no particular or exclusive claim on these obligations, as such general requirements only describe a particular required behaviour and not a duty or obligation related particularly to a fiduciary relationship. ${ }^{39}$

34 Langbein 2005114 Yale LJ 932.

35 Langbein 2005114 Yale LJ 932 and 988. See Leslie 200594 Georgetown LJ 2, criticising attempts by Langbein and others to transplant corporate concepts into the law of trusts and describe the analogy to corporate law as "fundamentally misguided".

${ }^{36}$ S 77(2)(a). See Havenga "Regulating Directors' Duties and South African Company Law Reform" 200526 Obiter 609-620. Compare the recent decision in Bester NO v Wright; Bester NO v Mouton; Bester NO v Van Greunen [2011] 2 All SA 75 (WCC), where the court stressed the fact that the director's actions did not benefit the company in any way. The only benefit was to the directors themselves, at the peril of the company. It was held as being an inappropriate use of funds, in breach of their fiduciary duties towards the company. See Stein The New Companies Act Unlocked - A Businesspersons' Guide (2011) 251.

37 See s 76(3) read with s 77(2)(a) of the Companies Act 71 of 2008.

38 Concise Edition English Dictionary (2005) on 48, 92 and 309. Cameron, De Waal, Kahn, Solomon and Wunsch Honorés South African Law of Trusts (2002) 263, state that the trustee must "observe exacta diligentia (scrupulous care)". Stephenson and Wiggins Estates and Trusts (1973) 71, submit that the trustee is under duty to the beneficiary to exercise such care and skill "as a man of ordinary prudence would exercise in dealing with his own property", and if the trustee is more skifful than the ordinary person, he must exercise such skill as he has.

39 See Alces 2009 35(2) Journal of Corporation Law 12, who further submits that the businessjudgment rule is an obstacle for directors personally liable for failures in decision-making, as long the decisions were made "on an informed basis, in good faith and in the honest belief that the action taken was in the best interests of the company." See also Valsan Understanding Fiduciary Duties 48. 
The question was raised as to whether the reference to "proper purpose" may include the horizontal constitutional duty of companies, which would include a prohibition against the use of "directorial powers contrary to the Bill of Rights". ${ }^{40}$ Section 7 of the Act does indeed stipulate, among others, the purpose of the Act as being the promotion of compliance with the Bill of Rights and the development of the economy. It is submitted that a concept such as the "best interest of the company" may be interpreted in future as more than the interests of the shareholders only. This is indeed the spirit of the Third Report of the King Committee on Governance, emphasising the convergence of the interests of shareholders with those of other stakeholders, such as employees, trade unions, and others. ${ }^{41}$

The Report divides directors' duties into two categories, namely the duty of care, skill and diligence, and secondly, fiduciary duties, with the latter being described as "the duty to act in the best interests of the company, to avoid conflicts, to not take corporate opportunities or secret profits, to not fetter their votes and to use their powers for the purpose conferred and not for a collateral purpose". ${ }^{42}$ These fiduciary duties have, however, not been spelled out in the Act. ${ }^{43}$

It is questionable whether section 76 contributes in any material way to the development of the normative content of the fiduciary duty.

\section{THE FIDUCIARY DUTY OF TRUSTEES}

A person in a fiduciary position "is not allowed to put himself in a position where his interest and duty conflict". ${ }^{44}$ Should he find himself in that position, "he is obliged by his trust to prefer the interest of his beneficiary". ${ }^{45}$ Fiduciary duties were traditionally framed in the two-fold convenient expressions of "the profit rule" and "the conflict rule" ${ }^{46}$ but it became trite law that the positive side of the fiduciary duty encompasses more than that. The so-called "positive duty of loyalty" has been expressed in the notion of good faith. ${ }^{47}$

40 See "Access to Justice: Human Rights abuses involving Corporations - South Africa", a project of the International Commission of Jurists, Geneva, Switzerland, 2010 www.icj.org (accessed 2011-02-12) 8-10.

41 See The Draft Code of Governance Principles for South Africa 2009 - King Committee on Governance https://www.ru.ac.za/media/rhodesuniversity/content/erm/documents/xx.\%20 King\%203\%20-\%20King\%20 Report.pdf (accessed 2015-04-06).

4211 and 12. The standard of care is described as follows: "a mixed objective and subjective test, in the sense that the minimum standard is that of a reasonably prudent person but a director who has greater skills, knowledge or experience than the reasonable person must give to the company the benefit of those greater skills, knowledge and experience".

43 See also Eser and Du Plessis "The Stakeholder Debate and Directors' Fiduciary Duties" 2007 19 SA Mercantile LJ 346. See Stein The New Companies Act Unlocked 251.

44 Lord Herschell in Bray $v$ Ford [1896] AC HL as quoted by Pettit Equity and the Law of Trusts (2006) 442. Compare also Martin Modern Equity (2005) 612 and 618

45 See Swain v Law Society [1981] 3 All ER 797. Stephenson and Wiggins Estates and Trusts 69 , refer to it as the "duty to loyalty", which is referred to by the Scots as "the most fundamental duty" of trustees.

46 See Moffat, Bean and Dewar Trusts Law: Texts and Materials (1994) 553-556, for more detail on the "no conflict of interest" rule and the "no secret profits" rule.

47 See Oakley Trends in Contemporary Trust Law (1996) 159-161. Compare further Martin Modern Equity 628-630. See also the facts in PPWAWU National Provident Fund $v$ 
Martin ${ }^{48}$ submits that liability for the trustee will arise if the fiduciary has used trust property, or the profit has been made by use of or by reason of the fiduciary position, or if there was a conflict of interest and duty, irrespective of whether trust property was used, and of whether the opportunity did in fact arise from the fiduciary relationship. ${ }^{49}$

In the fiduciary relationship between the trustee and the beneficiary, the trustee should at all times act in the best interest of the beneficiary, in concurrence with the powers and duties conferred upon him by way of the trust deed. The two poles of the relationship are, therefore, the fiduciary rights of the beneficiary on the one hand and the fiduciary obligation of the trustee on the other. ${ }^{50}$ This obligation is expressed in South African law as the requirement that a trustee should consistently act like a diligent et bonus paterfamilias. $^{5}$

The principle in Gross $v$ Pentz ${ }^{52}$ that even the beneficiary with only contingent rights has "vested interests" in the proper administration of the trust, was confirmed in Doyle $v$ Board of Executors, ${ }^{53}$ as far as it was established that trustees have fiduciary duties towards all beneficiaries. ${ }^{54}$

Chemical, Energy, Paper, Printing, Wood and Allied Workers' Union (CEPPWAWU) 2008 (2) SA 351.

48 Modern Equity 630. Some nexus between the fiduciary position and the profit made is required.

49 See Meinhard v Salmon (1928) 164 NE 545 546, as quoted in Olivier, Strydom and Van den Berg Trustreg en Praktyk (2009) 1-9, supporting the remark by Chief Justice Cardoza that "( $\mathrm{m}$ )any forms of conduct permissible in a work a day world for those acting at arm's length are forbidden to those bound by fiduciary ties. A trustee is held to something stricter than the morals of the market place. Not honesty alone but the punctilio of an honour the most sensitive is then the standard of behaviour". See also Moffat et al Trusts Law: Texts and Materials 544; and Kloppers "Enkele Lesse vir die Trustees uit die Parker-beslissing" 2006 Tydskrif vir die Suid-Afrikaanse Reg 414421 , stating that the fiduciary liabilities of the trustee require from last-mentioned to act with greater care than when dealing with his own estate. Watt Trusts and Equity 227 submits that the fiduciary duty in English law is not concerned with fairness between the trustee and the beneficiary, but is a matter of public policy "in order to set an example and to encourage good behaviour in all who hold positions of trust".

50 In Hofer $v$ Kevitt supra 408B it was submitted that the trustee does not automatically have a fiduciary duty towards a potential beneficiary. See Coetzee ' $n$ Kritiese Ondersoek na die Aard en Inhoud van Trustbegunstigdes se Regte Ingevolge die Suid-Afrikaanse Reg (LLD thesis, Unisa 2006) 357-358, in reference to Olivier Aspekte van die Reg insake Trust en Trustee met Besondere Verwysing na die Amerikaanse Reg (LLD thesis, University of Pretoria, 1982) 46. Coetzee 'n Kritiese Ondersoek na die Aard en Inhoud van Trustbegunstigdes se Regte 388,391 and 411 , indicates the close connection between fiduciary responsibility and the bona fides, both interlinking with the boni mores. See also Land and Agricultural Development Bank of South Africa v Parker 2005 (2) SA 77 (SCA) 86F-G, where it is stated that "the English law trust, and the trust-like institutions of the Roman and Roman-Dutch law, were designed essentially to protect the weak and to safeguard the interests of those who are absent or dead. This guiding principle provided the foundation for this court's major decisions over the past century in which the trust form has been adapted to South African law: that the trustee is appointed and accepts office to exercise fiduciary responsibility over property on behalf of and in the interests of another". Compare also Coetzee "Die Regte van Trustbegunstigdes: 'n Nuwe Wind wat Waai?" May 2007 De Rebus 19.

51 Olivier et al Trustreg en Praktyk 1-9, states that the trustee must comply with his duties "eerbaar en sonder die motief van selfbevoordeling en ooreenkomstig die vereistes van goeie trou".

521996 (4) SA 617 (A) 6281.

531999 (2) SA 805 (C) 813A. Coetzee submits in 'n Kritiese Ondersoek na die Aard en Inhoud van Trustbegunstigdes se Regte 397, that if there were any uncertainty about the fiduciary rights of beneficiaries, particularly after Hofer v Kevitt 1998 (1) SA 382 (SCA), it was removed 
From the facts in the National Provident Fund ${ }^{55}$ case it is clear that the fiduciary duty reaches much further than the extent of the profit-and-conflict rule. The court confirmed that the trustees owed a fiduciary duty to the fund and to its members, while the fund's primary object was the payment of benefits to its beneficiaries. The court, however, held that by following the union's policy, the union-appointed trustees had acted in breach of their fiduciary duties to do their best for the beneficiaries. The trustees' primary duty is not their representation of the union, and they do not represent the party that appointed them, and may, therefore, not place the views and interests of the party that appointed them above the interests of the fund or of union members. ${ }^{56}$

The separation of management and enjoyment in trusts is closely linked to the fiduciary nature of the role of trusteeship. The question of control over the trustees, whether it is by the founder, the beneficiaries, the co-trustees, or a third party, may sometimes be fundamental in determining the true existence of a trust. It is not only about form, but also about substance. Where there is no bona fide trust in existence, the legal consequence of the transaction may be a partnership or an agency and may result in the trustee being held personally liable in terms of the contract or for breach of its fiduciary duty. ${ }^{57}$ The question of independence must be evaluated both in terms of de facto and de iure control. In Badenhorst, ${ }^{58}$ the court emphasised that it was necessary to prove in the case at hand that the trustees were actually in de facto control. A trustee cannot operate in a "sleeping" position ${ }^{59}$ as one may

by the judgments in both Doyle $v$ Board of Executors supra and, Land and Agricultural Development Bank of South Africa $v$ Parker supra. See in particular the remarks by Cameron JA in Land and Agricultural Development Bank of South Africa v Parker supra 86F.

54 See Du Toit 20073 Stellenbosch LR 469-482. In Land and Agricultural Development Bank of South Africa v Parker supra 86F, Cameron JA, states that "the trust-like institutions of the Roman and Roman-Dutch law were designed essentially to protect the weak and to safeguard the interests of those who are absent or dead". Compare Pettit Equity and the Law of Trusts 442-452, for a discussion on the English position, where he refers to general rules like the duty to act without remuneration, and the limitations on trustees relating to the purchase of trust property.

55 PPWAWU National Provident Fund $v$ Chemical, Energy, Paper, Printing, Wood and Allied Workers' Union (CEPPWAWU) supra 351.

56 PPWAWU National Provident Fund $v$ Chemical, Energy, Paper, Printing, Wood and Allied Workers' Union (CEPPWAWU) supra 358E-361A. See also Van der Linde and Lombard "Nel $\checkmark$ Metequity Ltd 2007 (3) SA 34 (SCA): Identity of Interest Between Trustees and Beneficiaries in so far as Object of Trust is Concerned: Effect on Validity" 2007 De Jure 429 434 , where they submit that if a person who is administering property, is bound by the instructions of a third party, that the trustee is acting as an agent and not as a trustee.

57 It is trite law that a partnership cannot be formed without the contracting parties having the clear intention of establishing a partnership. See Pezzutto v Dreyer 1992 (3) SA 379 (A) 389. Contra Snyman-Van Deventer and Henning "Is die Essensialia van die Vennootskap Ondergeskik aan die Bedoeling van die Partye? 'n Oorsig oor die SA Reg" 2007 32(1) Journal for Juridical Science 87 115, criticising this requirement, stating: "Die bedoeling van die partye kan slegs dui op die bedoeling om aan die essensialia te voldoen en nie om ' $n$ vennootskap op te rig al dan nie." See further Ponelat v Schrepfer 2012 (1) SA 206 (SCA), where the court summarised the essentials of a universal partnership as follows: (a) each of the parties brings something into the partnership; (b) the business is carried on for the joint benefit of the parties; (c) the object is to make a profit; and, (d) the contract is legitimate. See also McDonald $v$ Young 2012 (3) SA 1 (SCA) in this regard.

58 Badenhorst $v$ Badenhorst 2006 (2) SA 255 (SCA).

59 Kloppers 2006 Tydskrif vir die Suid-Afrikaanse Reg 418. 
find in partnerships and even in the case of private companies where one of the parties is by agreement not involved in the daily decisions of the corporation. ${ }^{60}$ Trustees must act collectively; in the Parker case, the court stated that the rationale behind this is the fact that the trustees have jointownership of the assets of the trust, and "(s)ince co-owners must act jointly, trustees must also act jointly". ${ }^{61}$ Where a trustee acts without the authority of his co-trustees, he can neither represent nor bind the trust. ${ }^{62}$

It is submitted, however, that the principle that trustees should act jointly is not so much linked to the joint-ownership aspect as it is to the fiduciary nature of the trustees' function. When someone is burdened with a fiduciary duty, he cannot escape his responsibility by leaving it to his co-trustees to act in the interest of the beneficiaries towards whom he, too, has a duty. The exception is where the trust deed specifically provides for the limitation of the fiduciary duty.

The different duties and obligations of trustees, both common law and statutory, are all indicative of a position of trust, and include acting in good faith, ${ }^{63}$ granting security, ${ }^{64}$ observing the contents of the trust deed, ${ }^{65}$ taking possession of the trust property, keeping it separate, preserving it and making it productive ${ }^{66}$ acting with care, diligence and skill, ${ }^{67}$ act impartially, and giving account to the beneficiaries and the Master.

60 It is questionable whether any director can still act in a sleeping position after the introduction of the 2008 Companies Act. It is submitted that the position of non-executive directors may be under serious threat.

61 Land and Agricultural Development Bank of SA v Parker supra 85B. There are a number of decisions about trustees not acting jointly or according to the stipulations of the trust deed, eg, Land and Agricultural Development Bank of South Africa v Parker supra; Coetzee v Peet Smith Trust 2003 (5) SA 674 (T); Nieuwoudt v Vrystaat Mielies (Edms) Bpk 2004 (3) SA 486 (SCA); Man Truck \& Bus (SA) Ltd v Victor 2001 (2) SA 562 (NC); Vrystaat Mielies (Edms) Bpk v Nieuwoudt 2003 (2) SA 262 (O); and Thorpe v Trittenwein 2007 (2) SA 172 (SCA). See also Du Toit "Co-trusteeship and the Joint-action Rule in South African Trust Law" www.repository.uwc.ac.za/xmlui/bitstream/DuToitCo-trusteeship2013.pdf (accessed 2015-0424) for detailed discussion on the joint action rule.

62 See O'Shea NO v Van Zyl 2012 (1) SA 90 (SCA).

63 "Good faith" is an integral element of a fiduciary relationship. The Trust Property Control Act 57 of 1988 does not use the words "good faith", but refers in s 9 to "care, diligence and skill". It confirms the common law rule in Sackville-West v Nourse 1925 AD 516 534, that a trustee is obliged "to observe due care and diligence".

64 Although it is a common-law principle it was also legislated by way of $s 6$ of the Trust Property Control Act and can even be enforced by the Master of the High Court in spite of a trust deed that does not require security.

65 See the discussion by Pace and Van der Westhuizen Wills and Trusts (2007) 53. In Standard Bank $v$ Koekemoer 2004 (6) SA 498 (SCA) 504A, the court referred to some potential action by trustees which may be "ultra vires the trust deed or constitute a breach of trust prejudicial to the beneficiaries". See also Pettit Equity and the Law of Trusts 520, where it is submitted as a basic right of a beneficiary to have the trust duly administered in accordance with the provisions of the trust deed as well as the general law applicable to the trust.

66 See in this regard Administrators, Estate Richards v Nichol 1999 (1) SA 551 (SCA) 558I, where Scott JA, made the following remark: "Generally speaking, however, a trustee will as far as is practicable seek to spread the investments of the trust over various forms of undertaking in order to obtain a balance of stability and growth in the capital value of the trust and the income it produces." The court does not support the decision by the court a quo that the trustees are restricted to invest not more than $50 \%$ of the value of the trust estate in shares or unit trusts, because " $(\mathrm{t})$ here is nothing in the evidence to support the imposition of such a limit" (559E). See also Badenhorst v Badenhorst supra; Jordaan v Jordaan 2001 (3) 
In terms of English law, the paid trustee is charged with a higher standard of care, diligence, knowledge and skill than the unpaid trustee. ${ }^{69}$ Moffat et a ${ }^{70}$ states that the term "fiduciary" is abstract, with its core meaning being "[to be] under a duty of loyalty to some other person or body". The principle of managing the affairs of another is of a fiduciary nature. Kloppers ${ }^{71}$ states that the fiduciary liabilities of the trustee in South African law require him to act with even greater care than when dealing with his own estate. Oakley ${ }^{72}$ distinguishes between the fiduciary duty of the trustee and the fiduciary relationship between the trustee and the beneficiary. If a relationship is fiduciary, the characteristics of trust are taken to be at the heart of the entire relationship. The fiduciary relationship is, therefore, far more encompassing than a mere duty to act carefully and diligently and include minimum standards of good faith, disclosure, and a proper exercise of discretionary powers.

Coetzee $^{73}$ proposes that the rights of all trust beneficiaries primarily derive from the fiduciary relationship between the parties to the trust, although it is not the only source. He further submits that the fiduciary relationship, with the

SA 288 (C); Tijmstra v Blunt-Mackenzie 2002 (1) SA 459 (T), and s 11 of the Trust Property Control Act.

67 In Sackville-West $v$ Nourse supra 533, the court stated that a trustee had to use greater care in handling trust property than he might in dealing with his own property. The court went much further, however, and stated that no business risks should be taken by trustees. This limited approach was qualified 74 years later in Administrators, Estate Richards $v$ Nichol supra 558I, where Scott JA, made it clear that the test for prudent decisions, made with due care and diligence, is a question which must be decided on the facts of each particular case. He states as follows (557I): "An investment considered prudent in earlier times may rightfully be regarded as quite imprudent in the context of modern conditions. The ongoing and rapid decline in the value of money brought about by inflation, which has become a feature of our economy in the course of the past few decades, may well result in a sharp decline in the value of a monetary security".

68 S 19 of the Trust Property Control Act renders any person having an interest in the trust property the right to petition the court for an order directing the trustee to comply with certain requests or to perform certain duties. The position of trustee is one of fiduciary. See Cameron et al Honoré's South African Law of Trusts 323, stating that "Trustees, moreover, unlike a voluntary association, share a common fiduciary obligation to the fulfilment of the trust objects". See also the requirement of "utmost good faith" in s 2(a) of the Financial Institutions (Protection of Funds) Act 28 of 2001. See in general Pace and Van der Westhuizen Wills and Trusts 50-59. Compare also Estate Kemp v MacDonald's Trustee 1915 AD 491 499. In English law the common-law standard of conduct required of a trustee was that of the "ordinary prudent man of business" (Speight v Gaunt (1883) 9 App.Cas.1), until the Trustee Act 2000 provided that a trustee must exercise such care and skill as is reasonable. There are different scales of reasonableness for laymen and professionals.

69 See Harman J in Re Waterman's Will Trusts [1952] 2 All E.R. 1054, and Bartlett v Barclays Bank Trust Co. Ltd (No.1) [1980] Ch. 515. The distinction between lay and professional trustees is maintained in $\mathrm{s} 1$ of the Trustee Act 2000.

70 Trusts Law: Texts and Materials 545.

71 Kloppers 2006 Tydskrif vir die Suid-Afrikaanse Reg 421. In general see Balden and Rautenbach "Die Sorgsaamheidsplig van Trustees in die Uitvoer van hulle Beleggingsbevoegdhede: Kan ons by die Engelse Trustreg Leer?" 2005 3(1) Tydskrif vir Regswetenskap 91.

72 Trends in Contemporary Trust Law 158-160.

73 'n Kritiese Ondersoek na die Aard en Inhoud van Trustbegunstigdes se Regte 382, with reference to some secondary sources such as the source of the trust itself, like the trust deed. See also Olivier Aspekte van die Reg insake Trust en Trustee met Besondere Verwysing na die Amerikaanse Reg 116-117. 
ex lege rights and liabilities flowing from it, has probably developed from the English equity right, which is in essence a set of rules of fairness, with specific rights and liabilities exercised in a specific manner. This construction is not very different from the Roman-law principle of bona fides, and is found in most jurisdictions in some form or another. ${ }^{74}$

It is submitted that it is necessary to move past the profit-and-conflict approach, and even beyond a positive-duty-of-good-faith approach, to where a fiduciary relationship exists and the whole relationship is based on the principle of fides between the parties.

The law of equity has apparently slipped into South African law in various forms, and Bennett submits, quite convincingly, that the concept of ubuntu has established itself firmly in public law as a so-called African equity. ${ }^{75}$ The South African courts traditionally accepted that the rights of the beneficiary resulted from either the law of succession or the law of contract (ex contractu), and thus not directly from the fiduciary relationship (ex lege). According to Coetzee, however, this tendency is apparently changing. ${ }^{76}$ As all trust beneficiaries have legally enforceable rights, based on the fiduciary relationship, which results ex lege from the trust relationship as its primary source, ex contractu rights in favour of a beneficiary may not be as central as has been accepted in the past. ${ }^{77}$ Where a fiduciary relationship exists, that relationship continues independently and is directed by its own unique rules as far as the nature and content of the rights and liabilities relating to the relationship are concerned. ${ }^{78}$

Ultimately it remains imperative to distinguish between the very wide usage of the words "trust" and "trustee", which refer to a fiduciary relationship which was not necessarily created by a trust document, but which came into existence merely by binding someone to administer property, separate from his own, for the benefit of a third party. This would include someone acting as a tutor, curator, agent, guardian, director or executor burdened with a fiduciary duty.

74 Coetzee 'n Kritiese Ondersoek na die Aard en Inhoud van Trustbegunstigdes se Regte 388, refers to the position in a number of jurisdictions, where the additional rights of beneficiaries are called "tracing rights" (England), or "real subrogation" (Scotland), and others, where it is regulated by statute (Sri Lanka, Louisiana and Quebec).

75 Bennett "An African Doctrine of Equity in South African Public Law" 201257 Loyola LR 709726. Also in 20114 Potchefstroom Electronic LJ 14. See De Waal "The Abuse of the Trust (or "Going Beyond the Trust Form"): The South African Experience with Some Comparative Perspectives" 2012 76(4) The Rabel Journal of Comparative and International Private Law 1078 1099, who submits that some developments on South African trust law "have been typified as advancing 'equity'".

76 See the difference in approach in Hofer $v$ Kevitt (SCA) supra, compared to Gross $v$ Pentz supra 617. See also Slomowitz J, in Doyle $v$ Board of Executors supra 813A and Cameron $\mathrm{JA}$, in Land and Agricultural Bank of South Africa v Parker supra, for the newer and fresher approach to the aspect of the fiduciary nature of the trust.

77 See Coetzee 'n Kritiese Ondersoek na die Aard en Inhoud van Trustbegunstigdes se Regte 413. Compare Faris "Fiduciary Duties and Responsibilities when Dealing with Trust Assets" April 2011 De Rebus 16

78 See Coetzee 'n Kritiese Ondersoek na die Aard en Inhoud van Trustbegunstigdes se Regte 397-398.

79 See Coetzee and Van Tonder "The Fiduciary Relationship Between a Company and Its Directors" Obiter $2014285295-296$ and 308. 
It is submitted that the legislated content of the fiduciary duty for companies, namely care, diligence, skill, good faith, proper purpose and best interest, can also be applied when the fiduciary duty of the trustee is evaluated. ${ }^{80}$ Such an approach will go a long way towards aligning the trust and the corporation - especially where the trust fulfils the role of a business entity. The more pertinent question, however, is whether the requirements of care, diligence and skill collectively encompass the complete normative content of the concept of fiduciary duty. ${ }^{81}$

\section{POSITIVE LAW OR NORMATIVE CONTENT}

While positive law refers to the established legal rules in a particular context, regardless of the individual realities, the normative order deals with the (unwritten) rules that have actually manifested in practice, often regardless of what the contents of the positive law dictate. ${ }^{82}$

Vermeule $^{83}$ submits that the apparent disconnect often experienced between positive and normative legal theory can be ascribed to the gap between fact and value on the one hand, and the gap between internal and external perspectives on law on the other. The fact-value debate is often simplified by explaining it as the tension between what "is" versus what "ought to be", and is often bridged by arguing that the way things are and have been are normative in itself. ${ }^{84}$ In this sense, positive theory serves as both a source of and a constraint on normative theory ${ }^{85}$ Vermeule ${ }^{86}$ shows how normative approaches often depend on facts, as all rules are only regarded as good if they actually lead to good factual consequences. Some may argue that good values are commendable, but positive consequences are indispensable. Facts can, however, also constrain normative decision-making, either because it is too costly or because it is impossible or unfeasible. ${ }^{87}$

The South African trust milieu needed centuries of positivism before the landmark decision of Land and Agricultural Development Bank of SA $v$ Parker. ${ }^{88}$ It is submitted that the approach by the court, namely that the presence of an independent trustee in office may contribute to more effective separation between control and enjoyment, is normative in nature. The court

80 See Stein The New Companies Act Unlocked 240-253, for more on the duties of directors.

81 The concept "normative content" refers here to conformation to a standard of evaluative prescribed norms or rules. It is more than a mere description or statement of facts.

82 Savaneli 2010 The Journal Jurisprudence www.jurisprudence.com.au/juris6/savaneli.pdf (accessed 2015-03-09) 248.

83 "Connecting Positive and Normative Legal Theory" January 2008 10(2) Journal of Constitutional Law 387.

84 Vermeule January 2008 10(2) Journal of Constitutional Law 393. See also 391-393 for a discussion on tradition as a source of norms.

85 Vermeule January 2008 10(2) Journal of Constitutional Law 389. The debate on internal and external perspectives of law will not be discussed here in more detail as it is regarded as not relevant for the current discussion. In this article an internal legal perspective is applied. See also Vermeule January 2008 10(2) Journal of Constitutional Law 390.

86 Vermeule January 2008 10(2) Journal of Constitutional Law 391. See further Vermeule January 2008 10(2) Journal of Constitutional Law 390-391 for a discussion on the prescriptive theory.

87 Vermeule January 2008 10(2) Journal of Constitutional Law 394-395.

88 Supra. 
is of the opinion that an independent trustee is in a better position to balance the potential subjectivity of trustees who can also receive benefits from the trust. The court laid down a new policy to be followed by the Master of the High Court, without necessarily having the intention to create law in a positive sense. From a positive law context there are indeed many justifiable objections against this approach as it is often unpractical and costly, and in many instances do the founders of trusts actively resist such appointment. ${ }^{89}$

The presence of an independent trustee does not guarantee de facto separation between control and enjoyment, which may be from a positive law perspective a justifiable argument against the practice. Normativity, however, sometimes requires particular de jure interventions which may be undesirable within the context of legal positivism, but justifiable in a normative sense. ${ }^{90}$

Law does not only regulate the larger social structures in society, but it also purports to guide human behaviour in a more psychological context. It is not only about particular actions, but also about the reasons for such actions. ${ }^{91}$ Matters of a fiduciary nature are closely interwoven with aspects of morality, ethics and other social conventions. ${ }^{92}$

\section{CONCLUSION}

It is submitted that the fiduciary duty is more than merely a description or statement of facts. It actually burdens the trustee with having to conform to a particular standard of correctness through prescribed norms, rules or recommendations. The duty is not only descriptive but also evaluative. In most cases the courts will, when investigating the facts of a particular matter to determine whether a trustee has complied with his fiduciary duty or not, apply normative requirements in its quest. ${ }^{93}$ Not every factual conflict of interest will necessarily manifest in a breach of the fiduciary duty. Many trust deeds require from trustees to reveal potential conflicts of interest to their cotrustees and to refrain from participating in any discussions or decisions relating to such conflicts of interest. The co-trustees must thus evaluate the

89 The judgment was interpreted and applied by the Master's Offices in an unsatisfactory manner with limited understanding of any objective test for independence and with the apparent interpretative valuation that all family members do not qualify as being independent while all non-family are indeed independent. The requirement for an independent trustee is further in most jurisdictions only enforced in the case of so-called family trusts and not for business trusts.

90 Courts often use a so-called realist approach based on policy considerations and value judgments. See lyer "Using a legal realist approach to improve the communication skills of the law student" 20132 Speculum Juris 116 121. In the United States a difference is made between statutory and non-statutory appointments of trustees and a Code of Guidance was developed within the non-statutory environment. The Independent Pension Trustee Group describes an independent trustee as "an individual or corporate body with no direct or indirect involvement with the pension scheme, employer, or members, other than performing the duties of the trustees".

91 See Savaneli 2010 The Journal Jurisprudence www.jurisprudence.com.au/juris6/savaneli.pdf (accessed 2015-03-09) 247.

92 See Rotman 201191 Boston University LR 932-935. Compare Marsch "The normativity of law" 83-97 www.jura.uni-freiburg.de/institute/rphil/rphil/de/downloads/spaak-text (accessed 2015-06-20) 83-97.

93 Kidbrooke Place Management Association v Walton supra par 47, 54 and 55, sets an example where the court had to execute a normative approach in evaluating the particular actions of the trustee. 
risk relating to such conflicts, and the combination of fact and value will determine the exact contents of the fiduciary duty in the particular instance concerned. $^{94}$ The fact that a particular trust has no independent trustee in office does not necessarily result in a negation of a clear divide between control and enjoyment, neither does compliance with an ex lege requirement guarantee de facto results. ${ }^{95}$

As indicated above, the fiduciary relationship is much more than a mere contractual obligation. ${ }^{96}$ It creates a legal and moral duty, based on a combination of positive law, consisting of rules of engagement, prescriptions and fides, on the one hand, and normative law, which entails a justificatory process of weighing the underlying moral and ethical aspects thereof, on the other. Although presiding officers rarely consciously decide to consider both the doctrinal base and the desirability of the fiduciary obligation, the nature thereof is prone to such a double-dip test. It is submitted that, while the obligatory nature of the fiduciary obligation is embedded in positive law, the very nature of the concept of trust is filled with normative content. ${ }^{97}$

It is submitted that a proper understanding by legislators and courts of both the legal and moral contents of the fiduciary duty is necessary to develop a robust, principled body of fiduciary law that will result in legal certainty and create confidence in the many applications of trusts, including wealth creation, financial planning, beneficiary funds, generational transfers, business transactions, individual- and family-asset protection, and as vehicles for financial instruments. An approach that "a court will recognise a fiduciary relationship when it sees one", ${ }^{98}$ without necessarily understanding and appreciating the underlying contents and motivation, is not satisfactory.

94 See Vermeule January 2008 10(2) Journal of Constitutional Law 396-398, for an explanation of the "determinacy paradox", which may be relevant in the case of fiduciaries that know and understand the normative elements of their duty but are driven by their own selfish interests.

95 In Wiid $v$ Wiid NCHC 13-01-2012 case no $1571 / 2006$ par 14.2 and 15.1, the court decided that the trustees, including the independent trustee, acted like puppets of the deceased and did not exercise an impartial and independent discretion, which actions were negligent and harmful to the trust.

96 See Rotman 201191 Boston University LR 935, where it is stated that "fiduciary law facilitates situationally-appropriate justice in ways that the ordinary laws of civil obligation cannot".

97 Rotman 201191 Boston University LR 932.

98 See Rotman 201191 Boston University $L R$ 935, referring to a remark in Lefebvre $v$ Gardiner (1988), 27 B.C.L.R. 2d 294, 299 (Can. B.C.C.A.) 71, where such an approach was followed. 